\title{
A NEW STELIS (ORCHIDACEAE: PLEUROTHALLIDINAE) FROM THE WESTERN ANDES OF COLOMBIA
}

\author{
Guillermo A. Reina-Rodríguez ${ }^{1,4}$, Adam P. Karremans ${ }^{2}$, Francisco López-Machado ${ }^{1}$ \\ \& JIMENA CRUZ-SALCEDO ${ }^{3}$
}

\author{
${ }^{1}$ Grupo de Investigación en orquídeas, ecología y sistemática vegetal, \\ Universidad Nacional de Colombia, Sede Palmira, Colombia \\ 2Jardín Botánico Lankester, Universidad de Costa Rica, Cartago, Costa Rica \\ ${ }^{3}$ Departamento Administrativo de Gestión del Medio Ambiente - DAGMA. \\ Avenida 5AN No. 20N-08 Piso 11, Cali, Colombia \\ ${ }^{4}$ Author for correspondence: reirodriguez6@gmail.com
}

\begin{abstract}
Stelis excentrica, a new species endemic to the Cauca slope of the western Andes, municipality of Cali, Valle del Cauca, Colombia, is described and illustrated. It was found in the northern part of the Farallones de Cali National Park, in the vicinity of the protected area "El Danubio" administered by the Cali mayoralty. Stelis excentrica is similar to Stelis gigantissima from Ecuador but differs in the ocher-green flowers (vs. dark purple), the reniform petals ( $v s$. flabellate petals), subquadrate lip with a minute apicule ( $v s$. subcuneate without apicule). Reaching up to $30.6 \mathrm{~mm}$ from the apex of the dorsal sepal to the apex of the lateral sepal, Stelis excentrica probably has the largest flowers reported in any member of Stelis subgen. Stelis. Its $60 \mathrm{~cm}$ long inflorescence is only rivaled by that of Stelis gigantissima. Ecological notes, in situ photographs, typus illustration, maps, and a composite plate are provided.

RESUmen. Se describe e ilustra Stelis excentrica, una nueva especie de orquídea, endémica de la vertiente occidental de los Andes Occidentales, municipio de Cali, Valle del Cauca, Colombia. Stelis excentrica fue encontrada en la parte norte del Parque Nacional Farallones de Cali, en el área protegida "El Danubio" administrada por la alcaldía de Cali. Stelis excentrica es similar a Stelis gigantissima de Ecuador, pero difiere en sus flores verde-ocre ( $v s$. purpura oscuro), pétalos reniformes ( $v s$. pétalos flabelados), labelo subcuadrado, cortamente apiculado ( $v s$. subcuneado y no apiculado). Alcanzando $30.6 \mathrm{~mm}$ desde el ápice del sépalo dorsal al ápice del sépalo lateral, Stelis excentrica probablemente tiene las flores más grandes actualmente reportadas de cualquier otro miembro de Stelis subgen. Stelis. Su inflorescencia de $60 \mathrm{~cm}$ long solo rivaliza con las de Stelis gigantissima. Se proporcionan notas ecológicas, fotografías in situ, ilustración del typus, mapas y una lámina compuesta.
\end{abstract}

Key Words: biggest flower, Farallones de Cali, Stelis gigantissima, taxonomy

Introduction. With +1240 species in its broadest circumscription, the Neotropical genus Stelis Swartz (Orchidaceae) is the largest in subtribe Pleurothallidinae, and one of the largest genera of the Orchidaceae family (Karremans 2019). Many of the taxa occur in large sympatric populations restricted to the humid environment from Florida (USA), through Central America and the Antilles, to Brazil and Paraguay (Karremans 2013, GBIF 2020). Stelis is one of the most important epiphytic components of the Andean forest, especially the members of Stelis subgen Stelis which include over 1030 species with the typical Stelis flower morphology (Karremans 2019).
For Colombia, Luer (2016) reported 240 species of Stelis subgen. Stelis, of which Betancur et al. (2015) regarded 114 as endemic. Additional revisions of the Colombian members of subgen. Stelis (Luer 2016a, 2016b, 2017a, 2017b, 2018a, 2018b) revealed 235 new species. An exhaustive species-by-species count showed the new number of 496 species for the country. In this way, Colombia accounts for about $48 \%$ of the global diversity of that subgenus and the $40 \%$ of the genus Stelis in its broadest circumscription. Because of the complexity and variety of ecosystems, high rainfall, microclimate diversity and orographic factors, in Colombia, there are still gaps in our knowledge 
of orchid biodiversity, in particular, the forest canopy remains to be throughly explored (Reina-Rodríguez 2016, 2019).

Stelis is a taxonomically challenging genus. Many species are only known from historical illustrations and very brief descriptions, and herbaria are plagued with unidentified specimens and misidentifications. Moreover, currently there are few systematists specializing on it (Solano-Gómez 2014). In general terms members of subgen. Stelis can be recognized by the terminal, racemose, fascicled, few or multi-flowered inflorescences, the triangular flowers with almost identical sepals, tending to radial symmetry, diversely connate sepals much larger than the petals and lip, the very reduced petals usually with a thick margin, the thickened lip that is similar to the petals, and a very short, unwinged column with an apical stigma and anther (Luer 2003).

Recent studies in "El Danubio", in the north area of Farallones de Cali National Park, recorded 218 angiosperms species, 165 genera in 73 families. The most species-rich plant families in the areas are: $\mathrm{Ru}-$ biaceae (16 species), Orchidaceae (15), Araceae (10) and Gesneriaceae (10). (Giraldo-Rodríguez et al. 2016). From the 2017, to the present, the number of orchids reported in "El Danubio" increased five times, reaching 88 species as a result of a joint effort between the DAGMA ranger from the Cali mayoralty, Calidris Association and our team. Some of them are the first report for the country, making this place attractive for orchid studies and ecotourism.

During an expedition in 2019 to El Danubio-Peñas Blancas, an undescribed species belonging to Stelis subgen. Stelis was discovered and it is described herein.

Material and methods. The plant material was collected in "El Danubio" Farallones de Cali National Park, Western Andes of Colombia and preserved as spirits and dried specimens at the CUVC herbarium, Universidad del Valle in Cali. The spirit material was used to prepare the line drawing. The photographs were taken in situ, dissections of the plant and flower according to Lankester Composite Dissection Plate (LCDP) format using a Cannon EOS $60 \mathrm{D} \AA$, with 60 $\mathrm{mm}, 65 \mathrm{~mm} \mathrm{1-5X}$ and $100 \mathrm{~mm}$ macro lenses. The photographs were edited using Adobe Photoshop ${ }^{\circledR}$ CS4.
Location maps were prepared using ArcGIS 10, module ArcMap ESRI ${ }^{\circledR}$, the official shapefile of La Elvira was downloaded from (http://runap.parquesnacionales.gov.co). The conservation assessment complies with the criteria of the IUCN (2001). We used the website (http://es.climate-data.org) to determine the weather conditions in Colombia, and Ecuador. Authors and names of plants follow The International Plant Name Index, IPNI (2019) (http://www.ipni.org). The new species was also compared with all Stelis species described from Colombia (Duque 2010a, Duque 2010b, Luer 2016a, 2016b, 2017a, 2017b, 2018a, 2018b) to confirm uniqueness.

\section{TAXONOMIC TREATMENT}

Stelis excentrica Reina-Rodr. \& López-Mach., sp. nov. (Fig. 1-3).

TYPE: Colombia. Valle del Cauca: Municipio de Cali, Corregimiento Los Andes, sector Los Cárpatos. Microcuenca del río Pichindé, afluente del río Cali. Cabaña "El Danubio" Planta terrestre en epifitario, traída de los alrededores. Bosque subandino, 2252 m, 20 de marzo 2019, G. Reina-Rodríguez 2957, F. López-Machado, B. Bermúdez, J. Cruz. (holotype: CUVC-spirit; isotype COL) . Fig. 1-2.

Diagnosis: Stelis excentrica Reina-Rodr. \& LópezMach. is distinguished from Stelis gigantissima Luer by its elliptic, subpeciolate, obtuse leaf (vs. orbicularelliptic, sessile, rounded), inflorescence two times longer than the leaf blade (vs. three times longer), the ocher green flowers (vs. dark purple) with glossy reflexed sepals (vs. flat sepals), a subquadrate, shortly apiculate lip, (vs. subcuneate not apiculate), glenion in T-shape and rounded apically (vs. subtrilobed). The new species is also similar to Stelis superbiens Lindl. but is distinguished by the significantly longer inflorescence ( $60 \mathrm{~cm}$ vs. $15-30 \mathrm{~cm}$ long), the ocher green color flowers (vs. pale yellow suffused with purple), the much larger flowers, e.g. dorsal sepal 13-15 × 7.0-9.0 $\mathrm{mm}($ vs. $5-10 \times 6-10)$.

Plant terrestrial, $70-90 \mathrm{~cm}$ tall excluding the inflorescence, erect to sub-erect, monophyllus. Roots velamentous, flexuous, cylindrical. Ramicauls up to $60 \mathrm{~cm}$ long, erect to sub-erect, terete, enclosed by 1-2 appressed, sheaths around the middle and 


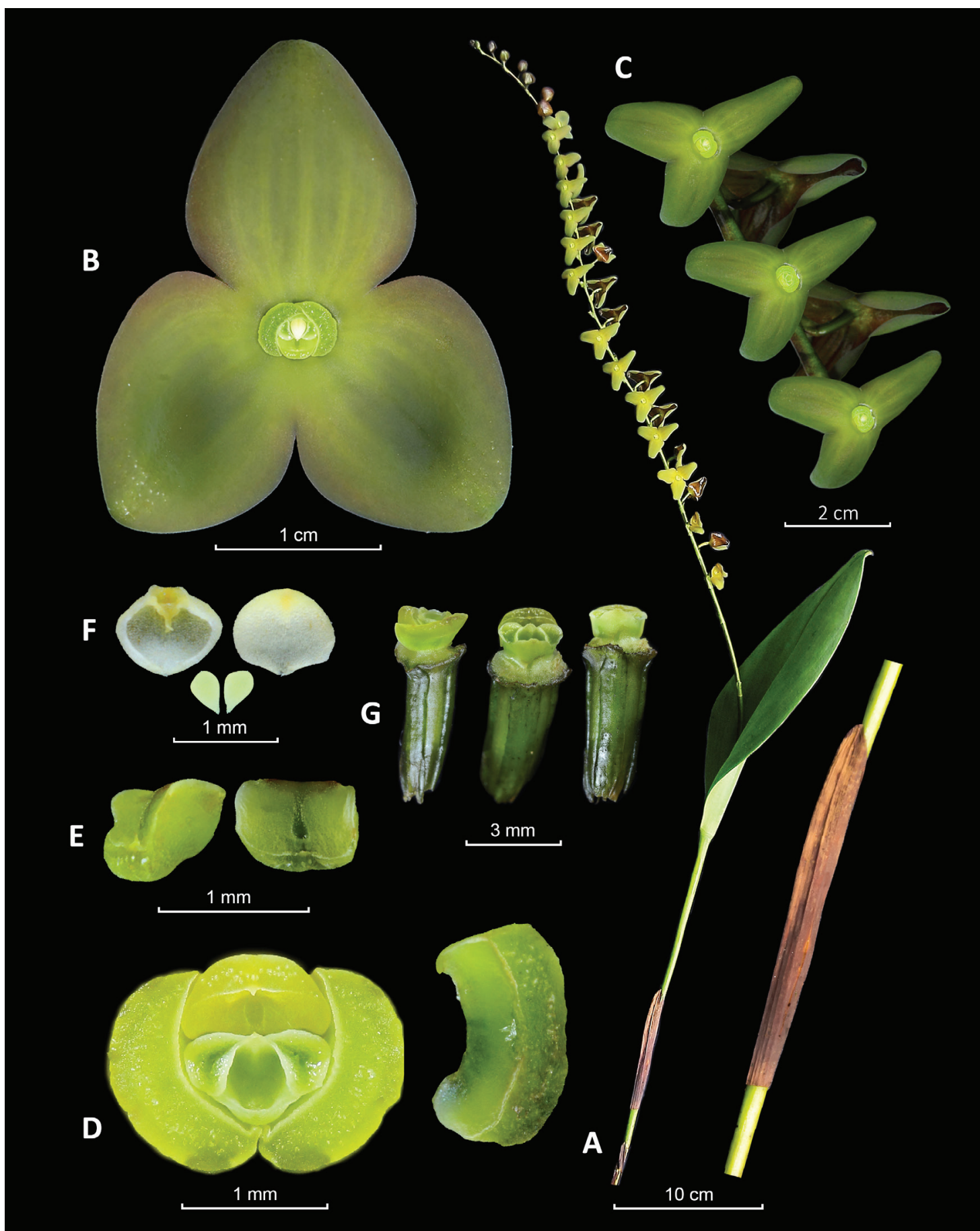

Figure 1. Lankester Composite Dissection Plate (LCDP) of Stelis excentrica Reina-Rodr. \& López-Mach. A. Habit and sheaths B. Frontal view of the flower C. Flowers in the inflorescence D. Dissected perianth. E. Lip in lateral and frontal view F. Pollinia and anther cap dissected G. Column and ovary, dorsal, frontal and overhead view. Photographs by Francisco López-Machado and Guillermo Reina-Rodríguez of the plant that served as type No. 2957 G. ReinaRodríguez et al. (CUVC-Spirit). 


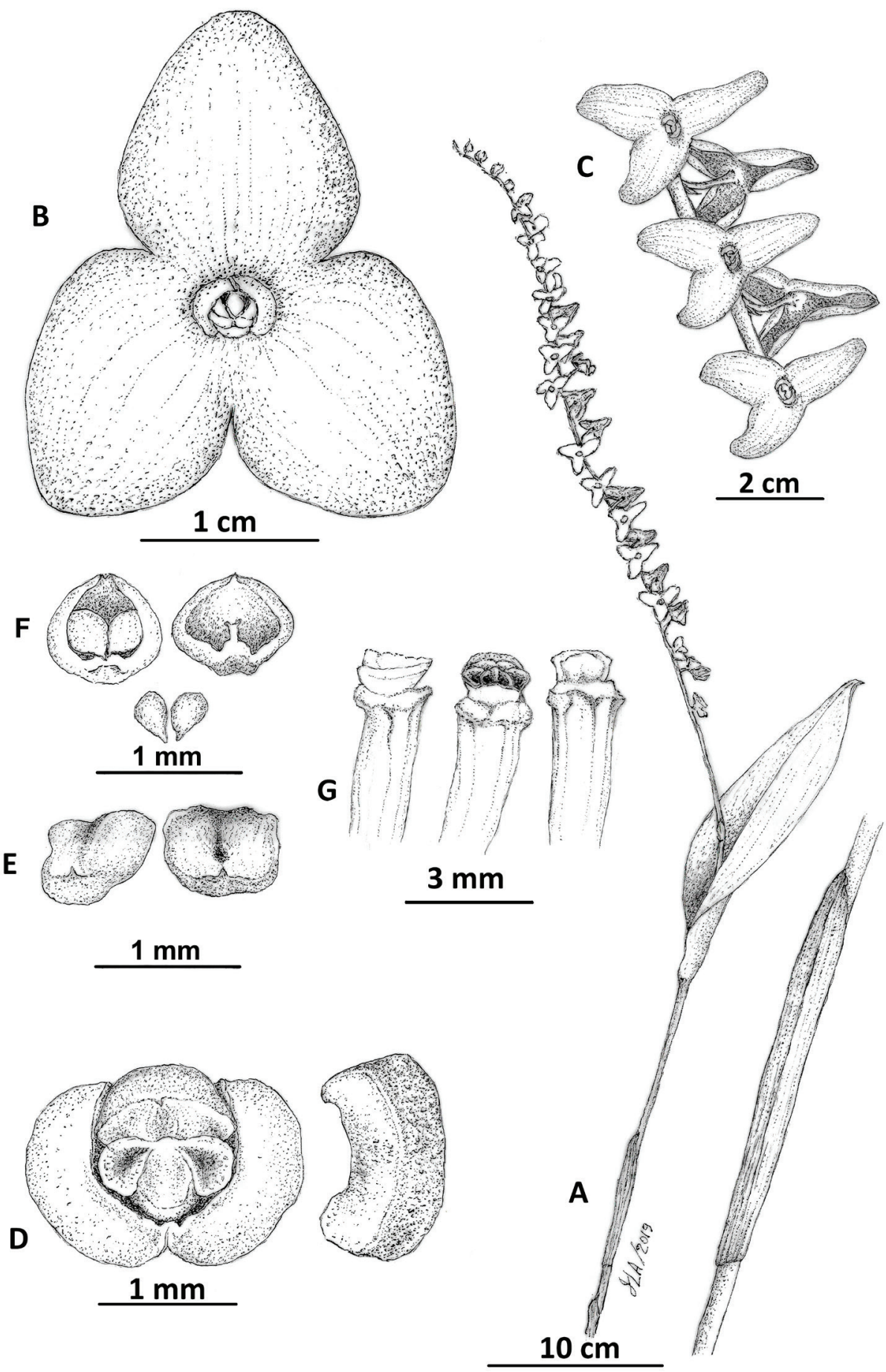

Figure 2. Ink illustration of Stelis excentrica Reina-Rodr. \& López-Mach. A. Habit and Sheaths B. Frontal view of the flower C. Segment of the inflorescence D. Petals, lip, and column in frontal view. E. Lip in lateral and frontal view F. Pollinia and anther cap dissected G. Column and ovary, dorsal, frontal and overhead view. Drawing by Jairo Larrahondo Aguilar from the type. 


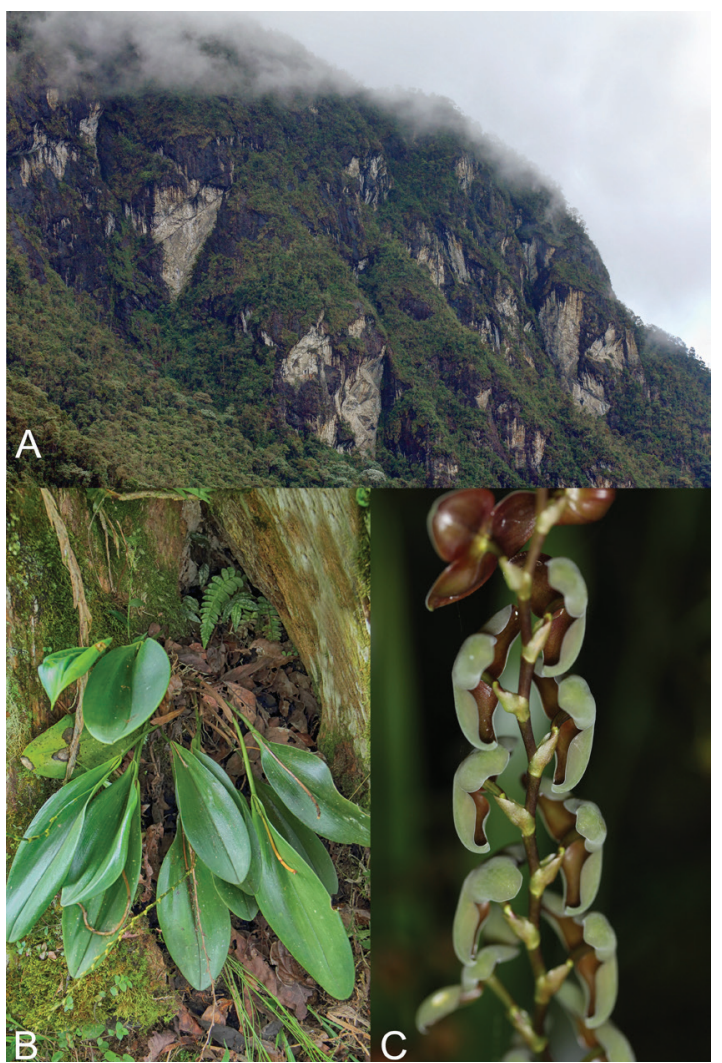

Figure 3. A. Peñas Blancas, cliff of Cretaceous period with vegetation where the type specimen of $S$. excentrica was found. B. Plant habit in situ. C. Floral bracts top view. Photographs by F. López-Machado (A-B) and G. Reina-Rodríguez (C).

base of the ramicaul. Sheaths 6-7-veined, tubular, oblique, papyraceous, broad and flattened towards the apex, 8.7-10.1 cm long. Leaf blade 26.8-28.2 $\times$ $10.3-10.5 \mathrm{~cm}$, coriaceous, lustrous, elliptical, apex acuminate, emarginate. Inflorescence $60 \mathrm{~cm}$ long, single, racemose, erect, decumbent in natural position, arising from apex of the stem, peduncle 15$17 \mathrm{~cm}$ long, with two tubulars, acuminate sheaths, the longest $8.7 \mathrm{~cm}$ long. Floral bracts $0.8-1.0 \mathrm{~cm}$ long, light green, obliquely funnel-shape. Pedicels green, arching, 0.9-1.0 cm. Flowers $2.6-3.1 \mathrm{~cm}$ in diameter, ochraceum green color, 25-34, simultaneously opening $3 / 4$ parts from the base and the last $1 / 3$ in flower buds. Ovary straight, glossy with ribs, $6.0-7.0 \times 1.0-2.0 \mathrm{~mm}$. Dorsal sepal, $13-15 \times$ $7.0-9.0 \mathrm{~mm}$, connate with lateral sepals in $0.2 \mathrm{~cm}$, ovate, rounded, markedly reflexed along the mar- gins, green-ochraceum with soft texture adaxially and shiny brown abaxially, subapically papillose, 5 -veined. Lateral sepals 12-14 × 7.0-11 mm, connate basally with dorsal sepal in $3 \mathrm{~mm}$, obliquely ovate, apex rounded, subapically papillose, 5-veined. Petals 1.7-2.3 × 0.8-1.0 mm, concave, embracing totally the column and partially the labellum, kidney shaped, apex broadly rounded, slightly overlapped each to other in the columnar side, thick margin with microscopic crystals dots (calcium oxalate). Lip 1.0-1.2 × 0.7-0.9 $\times 0.8-0.9 \mathrm{~mm}$, subquadrate, slightly concave, rounded, shortly apiculate, base truncate, hinged to the base of the column; $\mathrm{Cal}$ lus triangular with glenion in T-shape, raised, extended from the base to the middle of the lip, hirsute in its middle part and rounded apically. Column 1.0 $\mathrm{mm}$ long $\times 0.8 \mathrm{~mm}$ wide, erect, triangular in crosssection, widely bilobed stigmatic lobes with sharp margins and microscopic crystals dots. Anther 0.6 mm long x 0.4 wide, apical, orbicular-ovoid, cucullated. Pollinarium formed by two yellow pollinia, obovate, attenuated toward the base, $0.5 \mathrm{~mm}$ long $\times$ $0.3 \mathrm{~mm}$ wide, attached to elastic caudicles and drop of hyaline, disc-shaped, orange viscidium. Column not seen.

Eтymology: The name derived from the Latin excentricus, eccentric, referring to the unusual size of the flower and inflorescence.

Phenology: In their habitat the plant was in blooming in March, April, November and December; coinciding with the two rainy peaks that dominate the bimodal rainfall regime in the area

Conservation status: We assume that it is endemic to the Farallones de Cali since no records are known from the north or south of the western Andes. Its presence extension area is confined to less than $483 \mathrm{~km} 2$. It complies with Criterion B1a for the EN (Endangered) category according to IUCN (2012).

Ecology And Distribution: Stelis excentrica is known only from the type specimen found in the middle and upper part of the Cali river basin, in the Valle del Cauca department of Colombia, at 2200$2800 \mathrm{~m}$ of elevation. The average annual temperature is $17^{\circ} \mathrm{C}$. Precipitation is reported as between 1900 to $2100 \mathrm{~mm}$. This area has slopes of $20-50 \%$, 

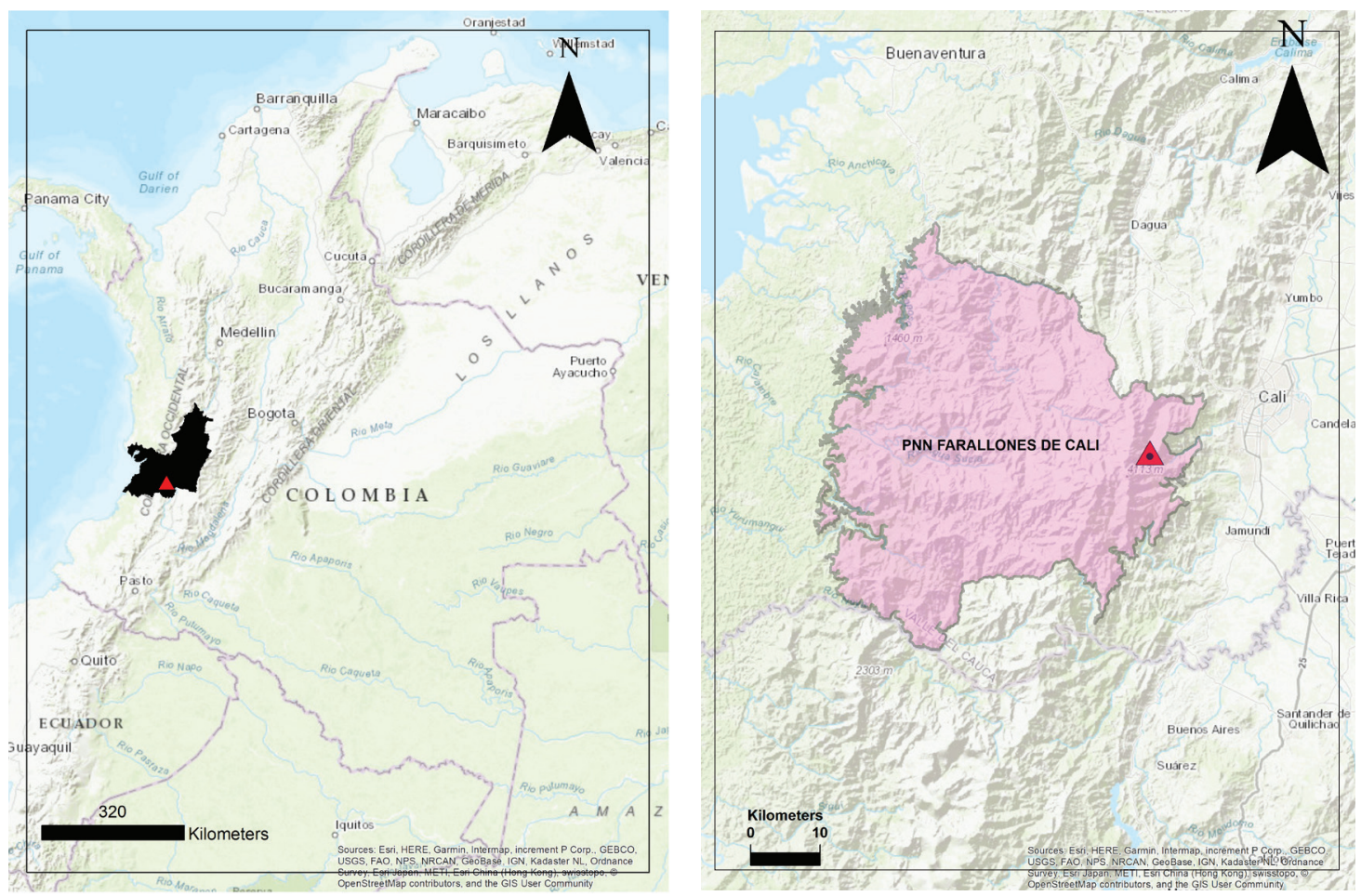

FIGURE 4: Map of location where the type specimen of S. excentrica Reina-Rodr. \& López-Mach. was collected.

on deep and well-drained soils from volcanic of Cretaceous (CVC 2010) (Fig. 3 A). The area was classified as Montane rain forest (Holdridge 1987); the humid winds coming from the Pacific Ocean, which, when hitting the mountain top, is condensed, producing haze and strong precipitations known as orographic rains. (DAGMA 2014).

The main plant elements associated with the new species are: canopy above $10 \mathrm{~m}$ : Quercus humboldtii Bonpl. (Fagaceae), Spirotheca rosea (Seem.) P.E. Gibbs \& W.S.Alverson (Malvaceae), Otoba lehmannii (A.C.Sm.) A.H. Gentry., (Myristicaceae). Subdosel species $<6 \mathrm{~m}$ : Brunellia comocladifolia Bonpl. (Brunelliaceae), Alchornea latifolia Sw. (Euphorbiaceae), Hedyosmum bonplandianum Kunth. (Chloranthaceae) and Miconia caudata DC. (Melastomataceae) (CVC 2015). In addition, there is a community of epiphytes dominated by the genus: Cyrtochilum Kunth., Epidendrum L., Lepanthes Sw., Masdevallia Ruiz \& Pav., Maxillaria Ruiz \& Pav., Oncidium Sw, and Pleurothallis R.Br.

At the present, this species is probably the largest flower of the subgenus Stelis registered. It differs from its rival Stelis gigantissima in the flower color (ocher green flowers (vs. dark purple); sepals with folded margins (vs. unfolded), sepals abaxially bright (vs. dull) and the triangular "T" shaped glenion of the lip (vs. subtrilobed). See (Table 1)

ACKNOWLEDGMENTS. The authors are grateful to Calidris association, Departamento Administrativo de Gestión del Medio Ambiente (DAMA) and the Corporación Autónoma del Valle del Cauca (CVC), through the contract No. 0685 of 2018. To the managers, Luis Fernando Castillo Calidris Association leader. Claudia Maria Buitrago, Catalina Silva and Ana Dorly Jaramillo from (DAGMA). The authors are also grateful to the DAGMA forest rangers: Bertulfo Bermudez, Carolina Meneses, Paola Alzate and Anderson Perafán, and Lucho Neira (Calidris) for aid with field work and to accompany on all expeditions in 2019 and Leonardo Sáenz, Tatiana Gutiérrez, Greg Ward, Mick Mittermeier, Maria Isabel Caicedo and Javier Serna for the rediscovery of the Farallones de Cali National park in 2017. Jairo Larrahondo Aguilar is thanked for the ink illustration. We thank the village of Los Andes, Peñas Blancas and Pichindé in the municipality of Cali for its help during field trips. Finally, the anonymous reviewers are thanked for their suggestions that helped to improve the manuscript. 
TABLE 1: Differences between Stelis excentrica vs. Stelis gigantissima, in terms of abiotic conditions and morphology.

\begin{tabular}{|c|c|c|}
\hline Traits & Stelis excentrica & Stelis gigantissima \\
\hline \multicolumn{3}{|l|}{ Abiotic conditions } \\
\hline Countries & Colombia Southwest & Ecuador East \\
\hline Biogeographic range & Western Andes middle lands & Amazon basin middle lands \\
\hline Life zone & Montane rain forest (Holdridge 1987) & Tropical moist forest (Holdridge 1987) \\
\hline Elevation & $2200-2800$ & $1000-1900$ \\
\hline Mean annual rainfall (mm) & $2000-2500$ & $2200-4000$ \\
\hline Mean temperture $\left({ }^{\circ} \mathrm{C}\right)$ & $17^{\circ} \mathrm{C}$ & $22.3^{\circ} \mathrm{C}$ \\
\hline \multicolumn{3}{|l|}{ Morphology/Phenology } \\
\hline Biotype & Terrestrial & Epiphyte to terrestrial \\
\hline Flowering & March, April, November, December & November \\
\hline Ramicauls (cm) & 59 & 35 \\
\hline Leaf blade size $(\mathrm{cm})$ & $28.2 \times 10.5$ & $25 \times 20$ \\
\hline Floral bracts & Oblique, acuminate, acute. & Oblique-Obtuse. \\
\hline Floral bracts $(\mathrm{mm})$ & $8.0-10.0$ & 3.0 \\
\hline Inflorescence long (cm) & 60 & 75 \\
\hline Ovary $(\mathrm{mm})$ & $6.0-7.0$ & 3.0 \\
\hline Sepals (mm) & $15.0 \times 11.0$ & $14 \times 7.5$ \\
\hline $\begin{array}{l}\text { Flower length (from apex of dorsal sepal } \\
\text { to apex of lateral sepal) }(\mathrm{mm})\end{array}$ & 30.6 & 27 \\
\hline Flowers color & Ocher green & Dark Purple \\
\hline
\end{tabular}

\section{LiterATURE Cited}

Betancur, J., Sarmiento, L.H., Toro-González, L. \& Valencia, J. (2015) Plan para el estudio y la conservación de las orquídeas en Colombia. Ministerio de Ambiente y Desarrollo Sostenible; Universidad Nacional de Colombia, Bogotá D.C. 336 pp.

Climate-data.org (2019). https://climate-data.org/info/privacy/ [visited 28/10/2019]

Corporación Autónoma Regional del Valle del Cauca- CVC- \& Fundación Agua Viva. (2010). Aunar esfuerzos técnicos y económicos para realizar el análisis preliminar de la representatividad ecosistémica, a través de la recopilación, clasificación y ajuste de información primaria y secundaria con rectificaciones de campo del mapa de ecosistemas. Informe técnico Convenio No. 256 de 2009.

Corporación Autónoma Regional del Valle del Cauca-CVC-, Acodal \& Biodiversa. (2015). Caracterización del predio "El Danubio", adquirido bajo el artículo 111 de la ley 99 de 1993 por el municipio de Santiago de Cali. Documento técnico. Convenio de asociación No 161 de 2014, 106 pp.

Duque, O. (2008). Orchidaceae Stelis Swartz.: Compendium. Ed. Universidad de Antioquia. Medellín, 466 pp.

Duque, O. (2010a). Nuevas especies colombianas de género Stelis (Parte I). Orquideología, 17(1), 5-34.

Duque, O. (2010b). Nuevas especies colombianas de género Stelis (Parte II). Orquideología, 17(2), 119-166.

Giraldo-Rodríguez, A. F. (2013). Informe final caracterización de flora y fauna de los predios del DAGMA y municipio: piedra grande, la cajita, la Yolanda, la carolina, lomas de quintero y "el Danubio". Convenio de asociación DAGMAFundación AMATEA No. 4133 de 2013. Documento técnico. Santiago de Cali, 55 pp.

GBIF.org (2020), Página de Inicio de GBIF. Disponible en: https://www.gbif.org [13 de mayo de 2020].

Holdridge, L. (1987) Ecología basada en zonas de vida. IICA. San José. Costa Rica, 216 pp.

IPNI (2019). The International Plant Names Index. Published on the Internet http://www.ipni.org [accessed 13 April 2019]

IUCN. (2012). IUCN Red List Categories and Criteria: Version 3.1. Second edition. Gland, Switzerland and Cambridge, UK: IUCN. iv $+32 \mathrm{pp}$ 
Karremans, A. P., Bakker, F. T., Pupulin, F., Solano-Gómez, R., \& Smulders, M. J. (2013). Phylogenetics of Stelis and closely related genera (Orchidaceae: Pleurothallidinae). Plant Systematics and Evolution, 299(1), 151-176.

Karremans, A.P. (2019). To be, or not to be a Stelis. Lankesteriana, 19(3), 281-343.

Luer, C.A. (2003) Pleurothallis. In: Hammel BE, Grayum MH, Herrera C, Zamora N (eds) Manual de plantas de Costa Rica, vol III. Missouri Botanical Garden Press, Missouri, 386-452 pp

Luer, C. A. (2009). Icones Pleurothallidinarum XXX. Lepanthes of Jamaica and Systematics of Stelis, Stelis of Ecuador, part four and addenda: systematic of Masdevallia, new species of Lepanthes from Ecuador, and miscellaneous new combinations. Monographs in Systematic Botany from the Missouri Botanical Garden, 115, 1-265.

Luer, C. A. (2016a). Icones Stelidarum (Orchidaceae) Colombiae. Harvard Papers in Botany, 21(1), 59-92.

Luer, C. A. (2016b). Icones Stelidarum (Orchidaceae) Colombiae II. Harvard Papers in Botany, 21(2), 193-225.

Luer, C. A. (2017a). Icones Stelidarum (Orchidaceae) Colombiae III. Harvard Papers in Botany, 22(1), 27-60.

Luer, C. A. (2017b). Icones Stelidarum (Orchidaceae) Colombiae IV. Harvard Papers in Botany, 22(2), 81-112.

Luer, C. A. (2018). Icones Stelidarum (Orchidaceae) Colombiae V. Harvard Papers in Botany, 23(1), 19-45.

Luer, C. A. (2018). Icones Stelidarum (Orchidaceae) Colombiae VI. Harvard Papers in Botany, 23(2), 139-178.

Pridgeon, A. M. and M. W. Chase. 2001. A phylogenetic reclassification of Pleurothallidinae (Orchidaceae). Lindleyana, 16(4), 235-271.

Reina-Rodríguez, G.A., Rubiano, J., Castro, F.A. \& Soriano, I. (2017) Orchids distribution and bioclimatic niches as a strategy to climate change in areas of tropical dry forest in Colombia. Lankesteriana, 17, 17-47.

Solano-Gómez, R. (2014). Three new species of Stelis (Orchidaceae; Pleurothallidinae) from Mexico. Phytotaxa, 158(3), 255-264. 